\title{
The Impact of Organizational Factors on Financial Performance: Building a Theoretical Model
}

\author{
Al Shahrani Saad M, Tu Zhengge \\ College of Economics and Business Administration, Central China Normal University
}

\begin{abstract}
The paper is purposively designed to study the linkages between organizational factors, including liquidity, leverage, asset utilization, market share position and firm size on financial performance in service firms. In assessing the linkages, the study recruits return on assets (ROA) and return on equity (ROE) as dependent variables to assess financial performance derived from the existence of the stated organizational factors. The aspect of financial performance in service firms is an important one as it reflects the effectiveness of the management. Additionally, the growth of productivity in service firms is traditionally low compared to the manufacturing firms; hence, the organization of factors in manufacturing firms has been quite documented in the literature to be linked with financial performance. This provokes the question of whether management practices and organizational factors that have enhanced financial performance in manufacturing firms can also be accounted for the service firms. The financial performance of the company is essential to measure management as the individuals and groups within the organization that contributes towards the financial objectives of the company. The proposed research framework can be of practical value for the firms. Managers can benefit from the outcomes of the paper by having a clear picture of organizational factors and conducting necessary research in order to find out the true nature of these factors.
\end{abstract}

Keywords: Firm Performance; Market share position; Liquidity; Asset utilization; Leverage; Firm size

\section{Introduction}

It is the objective of every profit-oriented organization to attain financial performance, which is seen as the metric for assessing the effectiveness of management. Iswatia and Anshoria, (2007) posit that the ability of the organization to align the people and resources to tasks that are strategic for attaining organizational performance, in moral and ethical ways that ultimately leads to sustainable competitive advantage. In measuring organizational performance, managers use financial performance and non-financial performance to assess their ability and that of the whole organization in moving the business towards financial performance. Both measurements have been confirmed as significant in illustrating companies' wellbeing. However, the extent to which a company is financially successful often determines the tangible benefits of management. Bonuses, chances of promotion and other benefits depend on the bottom line of the company. This fact further accentuates the emphasis which is given to making sure that companies' operations are profitable. Therefore, a number of factors have been studied in relation to various measurements of financial performance. Numerous ways and theories have been proposed to measure the profitability of the company.

A study in South Korea by Lee, (2008) that relied on panel data for the country from 2000-2006 on the ownership structure of the organizations and financial performance, which revealed that firm performance, is attained at a humpshaped level between the ownership structure concentration of the organization and firm performance. The study further provided some empirical results on the linkage between organizational ownership structure and firm performance, which showed a positive relationship. Another empirical study conducted in Greece by Liargovas \& Skandalis, (2008) on factors that impact the financial performance of an organization by distinguishing it from the nonfinancial performance. The findings indicated that the size of the firm and leverage are two important determinants of financial performance. The firms in Greece that were found to be profitable are large firms which build the strong competitive advantage with effective management. Firm size as a determinant factor has been validated by many scholars as positively significant in influencing financial performance of business firms. For instance, Prasetyantoko 
and Parmono,(2008) studied the determinants of performance at the corporate level of Indonesian companies and their study result showed positive indicators such company profitability. Another prior study conducted in developed nations particularly in US ant the UK by Antoniou et a.1, (2007) found a positive influence of leverage ratio and physical assets on the firm performance. The authors further argued that leverage ratio which positively affects firm performance is also influenced by conditions that are driven by market forces within the business environment. The study carried in Omani banking sector validated that the size of the bank and effective asset management play an important role in the attainment of the financial performance of banks in Oman.

As the extensive body of literature confirms the link between organizational factors and financial performance, a creation of a unified model, together with validation of particular relationships of the model is required. Therefore, the focus of this study is on financial performance aspects with strong emphasis on the factors that are directly related to financial reports of the organization. Taking into consideration that the measuring firm performance is rather challenging, and as there is no consensus among scholars and business practitioners on the metrics to be used in tracking the efficiency and effectiveness of individuals towards the organizational goals. In this study, return on assets and return on equity are relied upon to assess financial performance with the link to organizational factors. Furthermore, links between organizational factors of liquidity, asset utilization, leverage, market share position, firm size and financial performance of firms are conceptualized.

\section{Research Model}

Assessing firm performance is critical to establishing the importance of various factors and resources combined towards the business goals and objectives. No organization can afford to let the business system operate without evaluating and monitoring performance. Some scholars argue for the need of aligning performance metrics with that of the overall business goals (Hertenstein \& Platt 2000; Atkinson 2000). The effectiveness of management to organize people and resources in an organization is strategic for contributing to the synergy between organizational factors and firm performance. The research model constructed in this paper links the organizational factors towards achieving financial performance. The organizational factors such as liquidity, leverage, asset utilization, firm size, and market share are the independent variables. Financial performance is the dependent variable in this study and the selected performance metrics to measure it are the return on assets (ROA) and return on equity (ROE). Endogenizing this research framework is for the reason of selecting and using organizational factors to attain and improve organizational financial performance, therefore, is the focus of this research.

\section{Organizational Factors Influencing Firm Performance}

A comprehensive examination of the literature on financial and non-financial determinants of financial performance of an organization was employed to construct the research model provided in the figure above, which is elaborated below to represent organizational factors influencing firm performance. The choices of the organizational factors discussed below are of the researcher's judgment that they are more appropriate and can be easily quantified in assessing the performance of financial firms.

\subsection{Liquidity}

The current ratio is the common measure of liquidity. Liquidity is an important factor for the company in the capability of meeting the debt obligations by using the available cash and current assets that can be quickly turned into cash. The current ratio is measured by the current assets to current liabilities, which is recommended to be two is to one (2:1). The ratio of 2:1 shows the ability of the company to convert its assets into cash that can form part of the working capital. This working capital is a critical means towards attaining financial performance for the company. The ability of the company to convert assets into cash is equivalent to its ability to manage the working capital which has to be kept to normal levels to avoid the company in becoming insolvent. The liquid assets are useful for the company in times when external streams of finance to the company are not accessible, or the cost of using external finance is more than resorting to liquid assets to finance its operational expenses and investments. Liargovas and Skandalis (2008) are in support of holding higher liquidity as it served a contingency plan in dealing with the future uncertainties and kept as reserves that can be used in times of low earnings to settle short-term obligations for the company.

A comparative assessment of companies can be attained by using the different current assets and current liabilities towards financial performance (Louderback et al., 2000). The study done in Malaysian financial sector on 172 firms by 
Binti (2010) showed the relationship that is negatively significant between liquid assets and the financial performance of the firm. An empirical examination conducted by Eljely (2004) in Saudi Arabia using current ratio found the significant but negative relationship between liquidity and the financial performance of the firm measured by profitability on a sample of 29 service companies. Therefore, the following hypothesis can be proposed: H1: There is a significant negative relationship between liquidity and financial performance of the firm

\subsection{Leverage}

Leverage is an important ratio measured by total liabilities to total assets, which the company makes use of debt in financing assets for the business pursuit of achieving favorable financial performance. Equity holders treat leverage as an alternative for claiming residual to boost their financial performance (Rajan and Zingales, 1995). The study by Aquino (2010) covered firms that are listed and unlisted on the stock exchange in the Philippines and concluded by showing a positive relationship between the company's high debt ratio and its growth rate and profitability. Research conducted by Joshua (2005) on financial leverage revealed a positive return on equity through utilization of the ratio of total debt to total assets. An empirical study on the impact of financial leverage on the company's investment decisions done by Aivaziana et al (2005), found a negative correlation, in which Ahna et al (2006) add that the negative correlations between financial leverage and investment decisions are much strategic considering that they occur in less important sectors of the economy than when they occur in core strategic sectors. According to Youmatelo (2012), investment decisions have been found by scholars to be affected negatively by the patterns of financial leverage, and there is the indication of motivated to not invest in capital assets when the total debts to total assets are higher in companies. The following proposition can be derived:

H2: There is a significant negative relationship between leverage and financial performance

\subsection{Asset utilization}

Asset utilization as an organizational factor to determine the financial performance of the company is based on the clarification of assets that are crucial to the production or service processes necessary to drive the financial performance (Belanova, 2016). The consideration of asset utilization is significant towards identifying and measuring the capability and different functions of these assets owned by the company in ensuring the attainment of financial returns (Ellis, 1998). When assets are not effectively and efficiently utilized it leads to poor financial performance such as losses in the accumulation of revenue from investments. According to Fleming, Heaney and Mc Cosker (2005) posited that agency costs are highly to increase when assets are inefficiently and ineffectively utilized which is an indication of management not promoting the interests of the business owners. A study done by Okwo (2012) on fixed assets investment and its relation to the profitability of the company indicates a positive relationship between the two variables. While $\mathrm{Xu}$ and $\mathrm{Xu}$ (2013), based their research on testing the significance of achieving business performance from the optimal allocation of the assets structure and the statistical testing showed a significant correlation. Moreover, studies conducted by other various researchers have confirmed and affirmed the significant effect of efficient and effective utilization of assets on the financial performance of a company (e.g. Wu et al., 2010; Jose et al., 2010; and Seema et al., 2011). Based on the review above, the following can be tested:

H3: Effective utilization of the assets can contribute to the financial development of the company.

\subsection{Firm Size}

The literature in the field proposes different results regarding the influence of so-called "size effect." The research conducted by Pervan (2012) found the negative relationship between the size of the firm and financial profitability. It is stated that due to the presence of high market power, firms can charge higher prices for their products and services in the market. Moreover, high profitability of the firm can be the result of the economies of scale of good negotiating power of the firm with the suppliers. Moreover, Numerous scholars studied the link between the size of the firm and the financial returns arising from it, e.g. an empirical study conducted by Vijayakumar and Tamizhselvan (2010) significantly proved that there is a positive link between the size of the firm and financial performance. The study focused on the profitability aspect of the financial performance and found that big business firms have resources and capability to make a profit for the long term compared to the capabilities of small firms that are more of short to medium term in effectuating profitability. The quantitative results and analysis study conducted on 3035 Greek manufacturing business firms by Papadognas (2007) revealed that the size classes of business firms were positively and somewhat proportionally linked to the firms' profitability. Lee (2009) also examined the sources of firms' profitability and the analysis revealed that one of the strategic sources of profitability was the size of the business firm, which positively influenced and plays an important role in opening streams of cash inflows and performance in general. Most 
of the above studies were conducted in the manufacturing industries; however, there are similarities between manufacturing firms and that in the service industry. A study conducted in the service industry tested size-profit linkage by Amato and Burson (2007) found that any firm regardless of the size it can attain profitability. Thus, below can be proposed:

H4: Firms that have a large market share are believed to have higher profitability compared to those with small sized firms

\subsection{Market share position}

The resource-based view (RBV) posits that differences in performance of firms are owing to the resource ownership. The resource-based view of the firm is not considered only as the pure theoretical structure, but also significant in formulating the long-term strategy of the firm. The main focus of the resource based view focuses on using and relying on efficient usage of the resources to establish the competitive advantage of the company (Isanzu, 2015). However, such resources should be valuable, rare, and not easy to imitate, and substitute. To validate the above view the following scholars have studied and tested it in various industries and found such link is positive. For example, Anderson (1988) validated in his study that the efficiency of the business firm in overall, be it gaining a large market share was highly dependent on its resources. Business firms gain market share position higher than their rivalries when their resource or products are superior to that of competitors in the hearts and minds of customers. Superior products of an organization significantly impact competitive advantage in a positive manner, which translates into financial performance i.e. profitability. Sales performance which is the prerequisite to attaining financial performance is directly influenced by market share position (Robbins, 1994). Furthermore, Robbins (1994) adds that there is a linkage between the value of the whole organization and the market share position of the organization.

A study conducted by Mc Taggart, Kontes and Mankins (1994) reveals that the favorable financial returns in various forms amount into an organizational value which depends on two factors, that is market share positioning and having the competitive advantage over its rivalries to gain higher returns along with economies of scale. The above argument is in line with that of Porter (1998) in competitive advantage, in which he argues that having the cost advantage and product differentiation build an organization's market share position that consequently leads to sustained financial performance. In support of this view, Grundy (2002) posits that financial performance can be sustained and improved by increasing the market share position, whereby an organization's objective is to be the leader in the market which should be characterized by the potential of increasing shareholder value in the process. The following proposition can be derived:

H5: The higher share of market position is positively related to the high profitability of the firm.

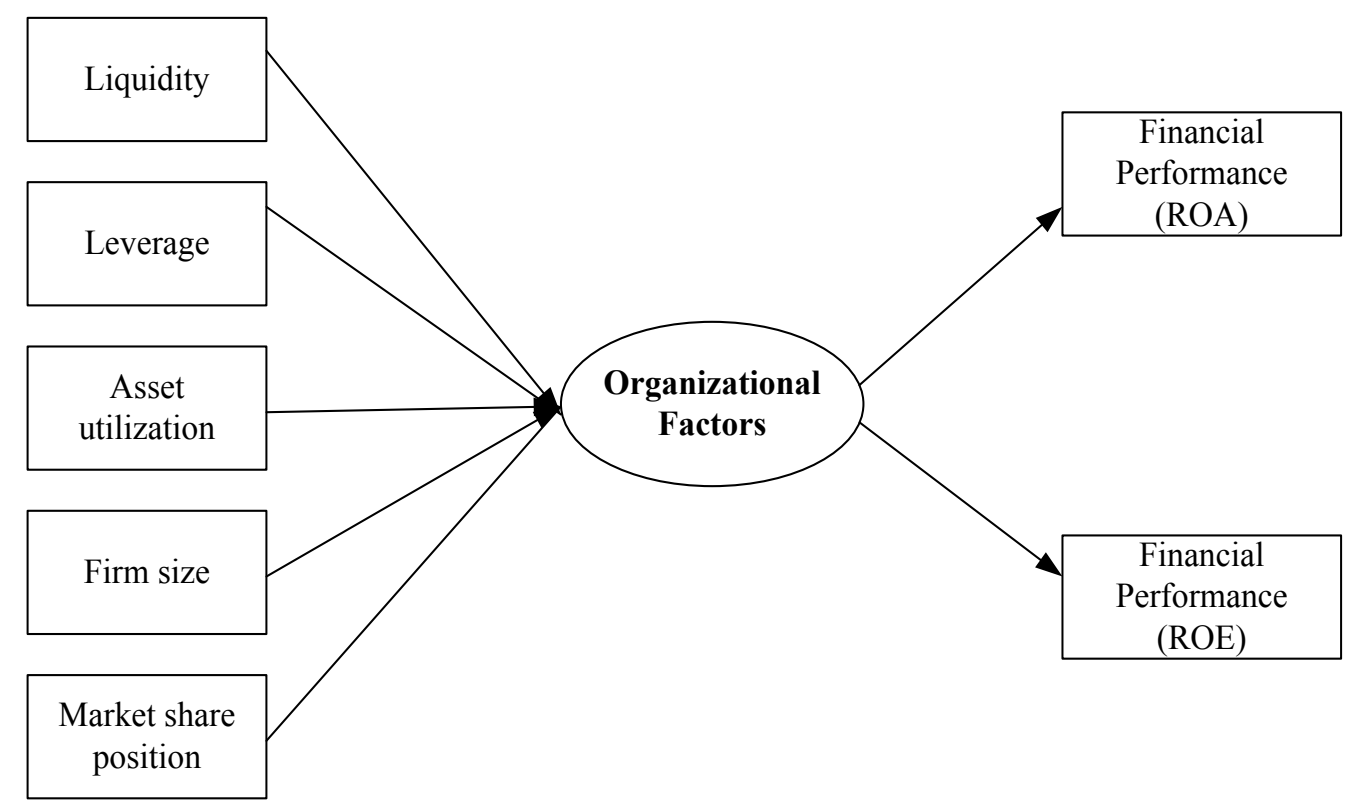

Figure 1: Conceptual framework of the study 


\section{Discussion and conclusion}

Managers are responsible for making decisions which are expected to move their organizations towards goals and objectives attainment. Managers are considered as one of the critical assets of the company as well alongside with the employees. The decision manager plays an important role in further aligning and determining the long-term objectives of the firm which may be critical to the success of the company. Hence, there is a strong need for the formulation of the specific model that addresses the relationship between organizational linkages and firm performance. High considerations of the factors including market share position, firm size, asset utilization, leverage and liquidity discussed in this article have been proven to be determinants of financial performance of organizations. It is a strategic move by managers to leverage on company assets and effective organization and management of people and asset utilization in increasing the size of the firm. Numerous studies have validated the positive linkage between firm size and the financial performance of the firm because the firm size is an important organizational factor that has a strong impact on the competitive position of the firm and wins a larger market share. In this study, it is, therefore, innocuous to posit that large companies have more power than small ones. Another important organizational factor that requires much attention is leverage. Shareholders' return on their investment can be increased as a result of leverage. However, a company that is heavily leveraged is to risk for many reasons such as low investment attractiveness particularly if it indicates signs of bankruptcy the business might be unable to find future new lenders and investors. Above all the important factors discussed in this article is the effective and efficient management and the organization of processes by managers to drive the business firm towards its goals and objectives i.e. financial performance.

The paper has illustrated the importance of financial performance in terms of ROE and ROA for company's development, and growth. The factors conducive to higher firm performance should be empirically tested on financial performance variables. A future study may employ similar measuring methodology as prior studies, which used scales and formulas of higher validity and reliability.

Return on assets (ROA) was analyzed in prior studies which were a combination of multiple scales adopted from previous research. In order to calculate the correct profitability ratio of the specific company, this variable was measured using a formula, return on assets was measured as net operating income before interest and taxes divided by total assets. Return on equity (ROE) was examined in prior studies which were a mixture of multiple scales selected from previous research. In order to measure a corporation's profitability by revealing how much profit a company generates with the money shareholders have invested, this variable was measured employing a formula, measured as net operating income before interest and taxes divided by issued and paid-up equity. A future empirical research should quantitative analyzes factors contributing to the financial performance of companies and will explain why some companies are more financially superior while focusing on specific relationships between organizational factors and financial performance. Thus, a new study taking an organizational factor view would explain financial performance

- New insight in a novel context of Saudi Arabian firms

\section{References}

- Ahna, K. (2006). Leverage and investment in diversified firms. Journal of Financial Economics, Vol. 79, pp. 317-337, CrossRef

- Aivaziana, J. (2005). The impact of leverage on firm investment: Canadian evidence. Journal of Corporate Finance, Vol. 11, pp. 277- 291, CrossRef

- Amato, L. and Wilder, R. P. (1985).The Effects of Firm Size on Profit Rates in U. S. Manufacturing. Southern Economic Journal, Vol. 52, No. 1, pp. 181 - 190, CrossRef

- Amato, L. H. and Burson, T. E. (2007).The effects of firm size on profit rates in the financial services. Journal of Economics and Economic Education Research, Vol. 8, Issue 1, pp. 67 - 81.

- Antoniou A, Guney, Y., \&Paudyal, K. (2008). The Determinants of Capital Structure: Capital Market Oriented versus Bank Oriented Institutions. Journal of Financial and Quantitative Analysis, 43(1), 59-92, CrossRef

- Binti, M. and Binti, M. S. (2010). Working capital management: The effect of market valuation and profitability in Malaysia. International Journal of Business and Management, Vol 5, No 11, pp 140-147.

- Eljelly, A. (2004). Liquidity - profitability tradeoff: an empirical investigation in an emerging market. IJCM , Vol. 14, No. 2, pp. 48-61, CrossRef 
- Ellis, R. (1998). Asset utilization: A metric for focusing reliability efforts (7th ed.). Marriott Houston: Westside Houston.

- Fleming, G. and McCosker, R. (2005). Agency costs and ownership structure in Australia. Pacific-Basin Finance Journal, Vol. 13, pp. 29-52, CrossRef

- Lee, S. (2008). Ownership Structure and Financial Performance: Evidence from Panel Data of South Korea. Corporate Ownership and Cntrol, 6(2), 1-30.

- Liargovas,p, \&Skandalis,k. (2008). Factor affecting firms financial performance The Case of Greece, University of Peloponnese.

- Louderback, et al. (2000). Managerial Accounting (9th ed.). South-western College Publishing Thomson Learning Asia Singapore p.3.

- McConnell, et al. (1995).Equity ownership and the two faces of debt. Journal of Financial Economics, Vol. 39, pp. 131-157, CrossRef

- McTaggart, Mankins,C, and Kontes, P.W., (1994). The value imperative: managing for superior shareholder returns. New York (N.Y.). Free press.

- Okwo, I. M. (2012). Investment in fixed assets and firm profitability: Evidence from the Nigerian Brewery industry. Eur. J. Bus. Manag, Vol. 4, No. 20, pp. 10-17.

- Prasetyantoko, A., \&Parmono, R. (2008).Determinants of Corporate Performance of Listed Companies in Indonesia MPRA Paper 6777, University Library of Munich, Germany.

- Rajan, R. G. and Zingales, 1. (1995). What do we know about capital structure? Some evidence from international data.Journal of finance, Vol. 50, No. 5, pp. 1421-1460, CrossRef

- Wu, J. and Zhu, M. (2010).Empirical Analysis of Rural Influencing Factors on Listed Agribusiness Financial Performance. Journal of Agricultural Economics and Management, Vol. 3, pp. 22-27.

- $\mathrm{Xu}, \mathrm{Z}$. S. and $\mathrm{Xu}, \mathrm{N}$. Z. (2013). The research of the optimal allocation of assets structure and business performance. Res. J. Econ. Bus. ICT, Vol. 8, pp. 1-5.

- Isanzu, J., (2015) Impact of Intellectual Capital on Financial Performance of Banks in Tanzania. Journal of International Business Research and Marketing, Vol. 1,

- Belanova, K., (2016) The Impact of National Environment of a Company on Its Financial Policy International Journal of Management Science and Business Administration, Vol. 2

- Pervan, M and Visic, J., (2012) Influence of firm size on its business success. Croatian Operational Research Review (CRORR), Vol. 3, 2012 